\title{
Assembly Politics and the Rhetoric of Honour in Chariton, Dio of Prusa and John Chrysostom*
}

\begin{abstract}
This article examines the assembly scenes that can be found in the writings of Chariton of Aphrodisias, Dio of Prusa and John Chrysostom, each of which contains a rich honorific vocabulary, better known to us from the epigraphic record. Whereas inscriptions generally do not provide much information on the political processes whose outcome they document, these texts enable us to catch a glimpse of real-life assembly politics. A careful analysis of the assembly scenes reveals an on-going tradition of Greek people politics, that is, a rhetorical exchange between elite and non-elite citizens in the assembly, which shows that the balance of power in the imperial Greek cities was not as heavily tilted against the demos as the current consensus would have it.
\end{abstract}

Keywords: imperial Greek city - popular assembly - ekklesia - civic honours - Chariton - Dio of Prusa - John Chrysostom.

The first-century novelist Chariton of Aphrodisias, his near-contemporary the philosopher-sophist Dio of Prusa and the late fourth-century saint John Chrysostom are rarely mentioned in the same context. One thing these authors do have in common is that they have produced the most vivid and elaborate popular assembly scenes of imperial Greek literature (i. e. Char. 1.1.11-12 and 8.7-8.8; Dio Or. 7.21-63 and Joh. Chrys. Educ. lib. 4-5). Despite their diversity in genre and chronological and geographical range, these texts all take the honours bestowed on citizens in return for benefactions to the community as a self-evident and central (although not necessarily commendable) aspect of civic life. Each of these assembly scenes contains a rich honorific vocabulary, centred on the ethical virtues of elite citizens, better known to us from the epigraphic record in which it found its most durable and prominent expression. ${ }^{\text {T }}$ The

* I would like to thank Koen De Temmerman, Arjan Zuiderhoek and Historia's two anonymous referees for their helpful comments and valuable criticism. Any remaining errors are entirely my own.

1 On this vocabulary see F. W. Danker, Benefactor: Epigraphic Study of a Graeco-Roman and New Testament Semantic Field (St. Louis 1982), 317-366; A. S. Henry, Honours and Privileges in Athenian Decrees: the Principal Formulae of Athenian Honorary Decrees (Hildesheim 1983); D. Whitehead, 'Cardinal Virtues: the Language of Public Approbation in Democratic Athens', CઐM 44 (1993), 37-75; F. Quass, Die Honoratiorenschicht in den Städten des griechischen Ostens: Untersuchungen zur politischen und sozialen Entwicklung in hellenistischer und römischer Zeit (Stuttgart 1993), 19-79; C. Veligianni-Terzi, Wertbegriffe in den attischen Ehrendekreten der Klassischen Zeit (Stuttgart 1997). 
vast mass of honorific inscriptions produced by the Greek cities of the first few centuries A.D. testifies to the proliferation of civic munificence, the exchange of gifts for honours, in this period. ${ }^{2}$ Yet, apart from the fact that honorific decrees continued to be issued by "the Council and the People" well into the third century A. D., little is known about the local political process of which this inscriptional evidence is only the end product. ${ }^{3}$ In this article we therefore turn to the assembly scenes of Chariton, Dio of Prusa and John Chrysostom which, as I will argue, enable us to catch a glimpse of real-life contemporary assembly politics and the ideological programme behind honorific epigraphy. My reading of these texts intends to demonstrate the existence of an on-going Greek tradition of 'people politics', that is, the rhetorical communication between elite and non-elite citizens in the popular assembly. This communication was firmly grounded in a civic ideology that benefited both elite and ordinary citizens and its reciprocal nature ensured that assembly politics remained a dynamic and interactive process even in the imperial period. ${ }^{4}$

This article challenges the still widely shared view that by the time of the Roman Empire the Greek cities, although democracies in name, had in fact transformed into highly oligarchic societies, dominated by a few wealthy families, who left the popular assemblies few other options than to rubberstamp decisions already taken by the elite-controlled councils. ${ }^{5}$ Whereas scholarship on the Hellenistic Greek city has increasingly challenged the old model of the undemocratic and obsolete polis, with recent studies stressing the vitality of democratic institutions and practices for the early Hellenistic period, studies on the imperial Greek city generally highlight the political power of elites and the depoliticization of the demos. ${ }^{6}$ The decisive shift to-

2 On civic benefactions in Roman Asia Minor see A. Zuiderhoek, The Politics of Munificence in the Roman Empire: Citizens, Elites, and Benefactors in Asia Minor (Cambridge 2009). On euergetism in general see P. Veyne, Le pain et le cirque: sociologie historique d'un pluralisme politique (Paris 1976); P. Gauthier, Les cités grecques et leurs bienfaiteurs (IV e-I er siècle avant J.-C.) (Athens 1985); M. Domingo Gygax, Benefaction and Rewards in the Ancient Greek city: the Origins of Euergetism (Cambridge 2016).

3 For the continuity of Greek decision-making bodies and procedures see P.J. Rhodes and D. M. Lewis, The Decrees of the Greek States (Oxford 1997), 548-549.

4 This article adopts a discursive approach to power which sees discourse and ideology as key elements in a complex process of social negotiation between mass and elite. For the theoretical assumptions and methodological background underpinning this approach see J. Ober, Mass and Elite in Democratic Athens: Rhetoric, Ideology, and the Power of the People (Princeton 1989) and Idem, The Athenian Revolution: Essays on Ancient Greek Democracy and Political Theory (Princeton 1996).

5 The most prominent articulation of this view is G.E.M. de Ste. Croix, The Class Struggle in the Ancient Greek World: from the Archaic Age to the Arab Conquests (Ithaca 1981), 300-326, 518-537, 609-617. See also Quass, Honoratiorenschicht (above, n. 1), 382-425, at 404; R. MacMullen, Romanization in the Time of Augustus (New Haven 2000), 4, 10; M. Wörrle, 'Maroneia im Umbruch. Von der hellenistischen zur kaiserzeitlichen Polis', Chiron 34 (2004), 149-167, and Idem, 'La politique des évergètes et la non-participation des citoyens. Le cas de Maronée sous l'Empereur Claude', in: P. Fröhlich and C. Müller (eds.), Citoyenneté et participation à la basse époque hellénistique (Geneva 2005), 145-161.

6 For the deconstruction of the 'old model' see esp. P. Gauthier, 'Les cités hellénistiques', in M. H. Hansen (ed.), The Ancient Greek City-State: Symposium on the Occasion of the 25oth anniversary of the Royal Danish Academy of Sciences and Letters, July, 1-4 1992 (Copenhagen 1993), 211-231; E. Gruen, 'The Polis in the Hellenistic World', in: R. Rosen and J. Farrell (eds.), Nomodeiktes: Greek Studies in Honor of Martin Ostwald (Michigan 1993); P.A. Harland, 'The Declining Polis? Religious Rivalries in the Early Roman Context', in: 
wards a more oligarchic government, a so-called 'régime des notables' or 'Honoratiorenregime', is often placed in the later Hellenistic period when a group of grand benefactors emerged whose lavish munificence was reciprocated with civic honours in an increasingly exuberant style. ${ }^{7}$ Although the pace and causes of this transformation remain the subject of debate, scholars of the Hellenistic period tend to agree that it was connected to the direct or indirect influence of Rome and that the beginning of the Principate marked its completion. ${ }^{8}$ Although the assembly continued to function well into the third century A. D., most accounts of civic politics in the imperial period are sceptical about the reality and extent of demos-participation and instead stress the council's dominance in the local decision-making process. ${ }^{9}$ In recent times this view has come under pressure from scholars pointing to the fact that the assemblies of the imperial period were well attended and continued to decide important issues. ${ }^{10} \mathrm{Nev}$ ertheless, in spite of these recent studies, the fact that the assemblies of the imperial

L.E. Vaage (ed.), Religious Rivalries in the Early Roman Empire and the Rise of Christianity (Waterloo 2006), 21-50. On Hellenistic democracies see V. Grieb, Hellenistische Demokratie: Politische Organisation und Struktur in freien griechischen Poleis nach Alexander dem Großen (Stuttgart 2008); S. Carlsson, Hellenistic Democracies: Freedom, Independence and Political Procedure in Some East Greek City-States (Stuttgart 2010).

7 On the establishment of a 'régime de notables' see C. Habicht, 'Ist ein Honoratiorenregime das Kennzeichen der Stadt im späteren Hellenismus?', in: M. Wörrle and P. Zanker (eds.), Stadtbild und Bürgerbild im Hellenismus. Kolloquium, München 24. bis 26. Juni 1993 (Munich 1995), 87-92; Fröhlich and Müller, Citoyenneté (above, n. 5); P. Hamon, 'Élites dirigeantes et processus d'aristocratisation à l'époque hellénistique', in: H.-L. Fernoux and C. Stein (eds.), Aristocratie antique: modèles et exemplarité sociale (Dijon 2007), 77-98.

8 For a critique of this view see A. Heller, 'La cité grecque d'époque impériale: vers une société d'ordres?', Annales (HSS) 64.2 (2009), 341-373, and Idem, 'Les institutions civiques grecques sous l'Empire: romanisation ou aristocratisation?', in: P. Schubert, P. Ducrey and P. Derron (eds.), Les Grecs héritiers des Romains (Geneva 2013), 201-240.

9 See M. Wörrle, Stadt und Fest im kaiserzeitlichen Kleinasien. Studien zu einer agonistischen Stiftung aus Oinoanda (Munich 1988), 133: 'gemacht wurde die Politik im Rat.' H.W. Pleket, 'Political Culture and Political Practice in the Cities of Asia Minor in the Roman Empire', in: W. Schuller (ed.), Politische Theorie und Praxis im Altertum (Darmstadt 1998), 211: '... at best the demos added a few footnotes to or emended a few passages in texts written by (members of) the bouleutic elite. Its role increasingly became a ritual one.' S. Dmitriev, City Government in Hellenistic and Roman Asia Minor (Oxford 2005), 330: 'Although the political activity of the people's assemblies became extinct, the people retained, albeit formally, the final say in political and administrative matters.' F. Millar, 'The Greek City in the Roman Period', in: H. M. Cotton and G. M. Rogers (eds.), Rome, the Greek World, and the East III (Chapel Hill 2006), 118: 'A tendency towards oligarchic regimes determined by class and wealth is undeniable.' 'What is in any case certain about the Greek, or Graeco-Roman, city of the imperial period is the central place occupied by the council (boule).'

10 G. M. Rogers, 'The Assembly of Imperial Ephesos', ZPE 94 (1992), 224-228; A. La Rocca, 'Diritto di iniziativa e potere popolare nelle assemblee cittadine greche', in: F. Amarelli (ed.), Politica e partecipazione nelle città dell'Impero romano (Rome 2005), 93-118; A. Zuiderhoek, 'On the Political Sociology of the Imperial Greek City', GRBS 48 (2008), 417-445; H.-L. Fernoux, Le Demos et la cité: communautés et assemblées populaires en Asie Mineure à l'époque impériale (Rennes 2011). On the vitality of the phylai as subdivisions of the demos see U. Kunnert, Bürger unter sich: Phylen in den Städten des kaiserzeitlichen Ostens (Basel 2012). For an extensive discussion of these last two works see C. Brélaz, 'La vie démocratique dans les cités grecques à l'époque impériale romaine. Notes de lectures et orientations de la recherche', Topoi 18.2 (2013), 367-399. 
period devoted much time voting honours continues to be interpreted as a sign of the "gradual reduction of the political power of the demos."

The evidence of the literary sources presented below suggests that our current understanding of civic politics in the imperial period still relies too much on the image of generous benefactors and grateful citizen communities portrayed by honorific epigraphy. Although inscriptions are an invaluable source for the political culture of the imperial Greek city, they generally do not present us with a great deal of information on the political processes whose outcome they document or on the civic social conflicts attested in literary sources. Thus, inscriptions tend to provide us with a rather idealized image of civic life in the imperial period. ${ }^{12}$ The exceptions to this rule are some of the larger epigraphic dossiers, for example, those recording the foundations of C. Iulius Demosthenes and C. Vibius Salutaris, which do give a glimpse into the politics behind their establishment. ${ }^{13}$ From these it appears that large-scale acts of munificence were not passively received by the people but rather constituted the product of a long process of negotiation between benefactor, council and assembly in which the latter played an important role. ${ }^{14}$ Another exception is an inscription recording a letter from the emperor in which the city of Ephesus is reproached for being unappreciative of the benefactor Vedius Antoninus who had donated and restored buildings rather than the more popular spectacles and distributions. ${ }^{15}$ Two further letters from

11 C. Schuler, 'Local Elites in the Greek East', in: C. Bruun and J. Edmondson (eds.), The Oxford Handbook of Roman Epigraphy (Oxford 2014), 254. Cf. M. W. Gleason, 'Greek Cities under Roman Rule', in: D.S. Potter (ed.), A Companion to the Roman Empire (Oxford 2006), 234: "[the assembly] spent more time voting honorific decrees than formulating substantive policy.” Cf. also P. Cartledge, Ancient Greek Political Thought in Practice (Cambridge 2009), 124-130; C. Schuler and K. Zimmerman, 'Neue Inschriften aus Patara I: zur Elite der Stadt in Hellenismus und früher Kaiserzeit', Chiron 42 (2012), 617-618.

12 On the limitations of epigraphical evidence see Dmitriev, City Government (above, n. 9), 140-157; G. Salmeri, 'Reconstructing the Political Life and Culture of the Greek Cities of the Roman Empire', in: O.M. van Nijf and R. Alston (eds.), Political Culture in the Greek City after the Classical Age (Leuven 2011), 200-202. For literary attestations of social conflict see G. Salmeri, La politica e il potere: saggio su Dione di Prusa (Catania 1982), 56-66, and Idem, 'Dio, Rome, and the Civic Life of Asia Minor', in: S. Swain (ed.), Dio Chrysostom: Politics, Letters, and Philosophy (Oxford 2000), 70-76.

13 For the Salutaris foundation see I.Ephesos 27 (104 A.D.); G. M. Rogers, The Sacred Identity of Ephesos: Foundation Myths of a Roman City (London 1991), 152-186. For the Demosthenes foundation see Wörrle, Stadt und Fest (above n. 9), and S. Mitchell, 'Festivals, Games and Civic Life in Roman Asia Minor', JRS 80 (1990), 183-293.

14 Rogers, Sacred Identity (above n. 13), and Idem, 'Demosthenes of Oenoanda and Models of Euergetism', JRS 81 (1991), 91-100. For some critical remarks on Rogers' positive evaluation of the People's influence in the foundation's establishment see the review by R. van Bremen, JRS 83 (1993), 245-246.

15 I.Ephesos 1491 (145 A. D.), discussed by M. Steskal, 'Zu den Stiftungen des M. Claudius P. Vedius Antoninus Phaedrus Sabinianus und ihrem Echo in Ephesos', Tyche 16 (2001), 177-188; A. Kalinowski, 'The Vedii Antonini: Aspects of Patronage and Benefaction in Second-century Ephesos', Phoenix 56 (2002), 109-149; A. Zuiderhoek, 'The Ambiguity of Munificence', Historia 56 (2007), 204. For a different interpretation see C. Kokkinia, 'Letters of Roman Authorities on Local Dignitaries: the Case of Vedius Antoninus', ZPE 142 (2003), 197-213, who argues that the emperor did not criticize the demos for obstructing Vedius' munificence, but rather that his letter, for which she provides an alternative reconstruction, praises the Ephesians for honouring Vedius. For arguments against this new interpretation see S. Frass, 'Der Euergetismus als Kunst, es allen recht zu machen: Konflikte um die Gemeinsinnigkeit wohltätiger Leistungen', in: M. Jehne and C. Lundgreen (eds.), Gemeinsinn und Gemeinwohl in der römischen Antike (Stuttgart 2013), 110-113. 
the emperor even suggest that Vedius' generosity was only honoured reluctantly after the emperor's intercession. ${ }^{16}$ This exceptional inscriptional evidence thus suggests that the cooperation of the community in the honorific process was not as self-evident as it appears from the bulk of honorific epigraphy.

In the following pages we turn to the assembly scenes of Chariton, Dio of Prusa and John Chrysostom in order to gain new insight into contemporary assembly politics and the role of the people in the political processes behind civic honours. This analysis is not only historically relevant, but also has implications for our current understanding of these literary texts, which, as I aim to show, were more closely linked to contemporary civic politics than has been recognized. Although literary scholarship no longer approaches imperial literature as an isolated phenomenon standing outside the structures of power, most studies focus on issues of empire and identity, whereas studies that do address the local dimension only stress how displays of education and rhetorical ability legitimised the elites' political dominance. ${ }^{17}$

\section{Chariton's Chaireas and Callirhoe}

We will first consider two assembly scenes from Chariton's Chaireas and Callirhoe commonly dated to the first or early second century A. D. ${ }^{18}$ The story is set in the world of the late fifth century B. C. and revolves around the troubled love affair between Chaireas and Callirhoe, the children of Syracuse's two leading citizens. Despite the fictitious nature and explicit historical setting of the narrative, it is clear that the novel also contains anachronistic elements reflecting contemporary imperial society and its Zeitgeist. ${ }^{19}$ Although recent studies have drawn attention to the political and ideological dimensions of the ancient Greek novel in relation to the imperial power of Rome, the potential of Chariton's novel as a source of information on contemporary civic politics has not yet been recognized..$^{20}$ Nevertheless, it is the local civic context

16 I.Ephesos 1492-3 (149/150 A. D.). Cf. Zuiderhoek, Politics of Munificence (above, n. 2), 109.

17 See e.g. S. Swain, (ed.), Hellenism and Empire: Language, Classicism, and Power in the Greek world AD 50-250 (Oxford 1996); T. Schmitz, Bildung und Macht: zur sozialen und politischen Funktion der zweiten Sophistik in der griechischen Welt der Kaiserzeit (Munich 1997).

18 C. Ruiz-Montero, 'Aspects of the Vocabulary of Chariton of Aphrodisias', CQ n.s. (1991), 484-489, and Idem, 'Chariton von Aphrodisias: ein Überblick', ANRW (1994), 1008-1012; C. Hernández Lara, Estudios sobre el aticismo de Caritón de Afrodisias (Amsterdam 1994); E.L. Bowie, 'The Chronology of the Earlier Greek Novels since B. E. Perry: Revisions and Precisions', Ancient Narrative 2 (2002), 54-55; S. Tilg, Chariton of Aphrodisias and the Invention of the Greek Love Novel (Oxford 2010), 36-79.

19 E. L. Bowie, 'The Novels and the Real World', in: B. P. Reardon (ed.), Erotica Antiqua: Acta of the International Conference on the Ancient Novel (Bangor 1977), 91-96, and Idem, 'The Construction of the Classical Past in the Ancient Greek Novels', in: S. Eklund (ed.), $\Sigma v \gamma \chi a ́ p \mu a \tau \alpha:$ Studies in Honour of Jan Fredrik Kindstrand (Uppsala 2006), 1-7; A. Billault, 'De l'histoire au roman: Hermocrate de Syracuse', REG 102 (1989), 540-548.

20 D. R. Edwards, 'Defining the Web of Power in Asia Minor: the Novelist Chariton and his City Aphrodisias', Journal of the American Academy of Religion 62 (1994), 699-718; Swain, Hellenism (above, n. 17), 66-72; S. Schwartz, 'Rome in the Greek Novel? Images and Ideas of Empire in Chariton's Persia', Arethusa 
which is immediately evoked in the novel's opening lines when the narrator identifies himself as an Aphrodisian scribe working for the rhetor Athenagoras (Char. 1.1.1). It can even be argued that the most obvious anachronistic presence in the text is the frequently intruding external narrator. ${ }^{21}$ Although the first part of the self-identification "Mister Charming from the City of Aphrodite" could very well be a pseudonym, the names of Chariton and Athenagoras do occur in the epigraphic record of Aphrodisias. ${ }^{22}$ Whatever the truth behind the narrator's self-identification may be, it must have been meaningful for the text's implied reader. It has been argued that by making himself known in this way the narrator stimulated the educated readership of the novel to read the story's anachronisms against his self-proclaimed identity in an attempt to bridge the gap between the classical, fictional world and that of the present. ${ }^{23}$

In line with this insight, I will argue that the rhetoric of honour found in Chariton's assembly scenes constitutes a contemporary political discourse that anchors the fiction in the real extra-diegetic world of civic politics and stresses its extraordinary nature. ${ }^{24}$ After this, we will look at the ways in which the rhetoric of honour is used by the characters in the story. In this way I aim to (1) shed some new light on how these ekklesia scenes were read in antiquity and (2) to improve our understanding of assembly politics in the imperial Greek city.

The first assembly scene takes place at the very beginning of the novel. After Chaireas and Callirhoe fall in love, it becomes clear that there is no future for the two protagonists, since their fathers, Ariston and Hermocrates, are entangled in a political rivalry. Devastated by the impossibility of marriage Chaireas stays home unable to engage in his usual activities at the gymnasium which becomes a deserted place in his absence (1.1.10). The frustrated love affair thus affects the public life of Syracuse and

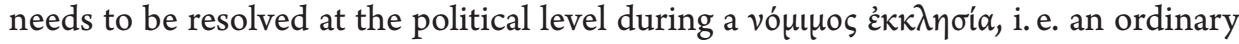

36 (2003), 375-394; S. D. Smith, Greek Identity and the Athenian Past in Chariton: the Romance of Empire (Groningen 2007).

21 On the obtrusive character of this narrator see J. R. Morgan, 'Chariton', in: I. J. F. de Jong, R. Nünlist and A. Bowie (eds.), Narrators, Narratees, and Narratives in Ancient Greek Literature (Leiden 2004), 479-487.

22 Tr. K. De Temmerman, 'Chariton', in: I.J. F. de Jong (ed.), Space in Ancient Greek Literature (Leiden 2012), 483. On the possibility of this being a pseudonym see T. Whitmarsh, Narrative and Identity in the Ancient Greek Novel: Returning Romance (Cambridge 2011), 26. For the inscriptions see IAph2007 12.1111-2 and 12.1018, already cited by E. Rohde, 'Zum griechischen Roman', RhM 48 (1893), 139-140. For a recent discussion see J. Reynolds, 'The First Known Aphrodisian to hold a Procuratorship', in P. Scherrer, H. Taeuber and H. Thür (eds.), Steine und Wege: Festschrift für Dieter Knibbe zum 65. Geburtstag (Vienna 1999), 327-334.

23 This has been argued by Bowie, 'Construction' (above, n. 19), 5, 19. On the readership of the ancient novel see E. L. Bowie, 'The Readership of Greek Novels in the Ancient World', in: J. Tatum (ed.), The Search for the Ancient Novel (Baltimore 1994), 435-459, and Idem, 'The Ancient Readers of the Greek Novels', in: G. Schmeling, The Novel in the Ancient World (Leiden 1996), 87-106; S. A. Stephens, 'Who Read Ancient Novels?', in: Tatum, Search for the Ancient Novel (above, n. 23), 405-418; J. R. Morgan, 'The Greek Novel: towards a Sociology of Production and Reception', in: A. Powell (ed.), The Greek World (London 1995), 137-139.

24 For practical reasons I only refer to a limited number of inscriptions, although many more are available. Cf. J. Reynolds, C. Roueché and G. Bodard (eds.), Inscriptions of Aphrodisias (2007), available online at $<$ http://insaph.kcl.ac.uk/iaph2007>. 
assembly meeting convened regularly and in accordance with the laws of the city. ${ }^{25}$ Although the agenda of a regular assembly was normally well-defined, the Syracusan demos seize the opportunity to make a public appeal to Hermocrates: ${ }^{26}$

A regular assembly took place at this time. When the people had taken their seats, their first and

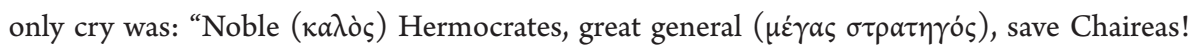
That will be your finest moment! The city pleads for marriage, today, of a pair worthy of each other!" Who could describe that assembly? It was dominated by Eros. Hermocrates loved his country ( $\varphi$ ı ó $\pi \alpha \tau \rho \varsigma)$ and could not refuse what it asked (1.1.11-12). ${ }^{27}$

The laudatory epithets used in the popular acclamation and the narrator's description of Hermocrates often occur in honorific inscriptions from imperial Aphrodisias. ${ }^{28} \mathrm{~A}$ first-century inscription, for example, honours a certain Adrastus as "a great man who

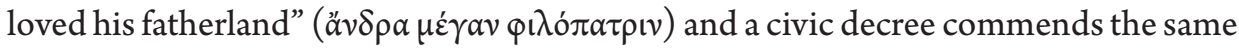

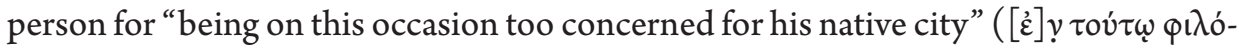
$\pi \alpha \tau \rho(\varsigma) .{ }^{29}$ Another inscription honours Athenagoras son of Athenagoras as "a fine and

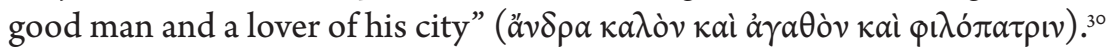

Honorific language also features prominently in the assembly meeting at the end of the novel (8.7-8), summoned in response to the unexpected return of the united couple. At the end of the assembly meeting Chaireas proposes to reward his friend Polycharmus for saving his life on several occasions:

Chaireas checked the applause and said: "I and Callirhoe express, in your presence, our gratitude ( $\chi \alpha \dot{\alpha} \rho v)$ to my friend Polycharmus. He has shown devotion ( $\varepsilon \dot{v} v o เ \alpha v \dot{\varepsilon} \pi \varepsilon \delta \varepsilon \dot{\xi} \xi \alpha \tau)$ and true loyalty ( $\pi \dot{i} \sigma \tau \imath v \dot{\alpha} \lambda \eta \theta \varepsilon \sigma \tau \dot{\alpha} \tau \eta \nu)$ to us; with your agreement, let us give him my sister as his wife -

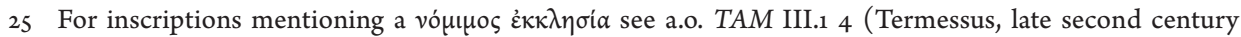
A.D.), with O.M. van Nijf, 'Public Space and Political Culture in Roman Termessos', in: van Nijf and Alston, Political Culture (above, n. 12), 215-242; Syll. ${ }^{3} 852$ (Thera, mid-second-century A. D.); I.Ephesos 27A.53-54 (above, n. 13). For a well-known literary parallel see Acts (19.29-41), where an ad hoc assembly instigated by the Ephesian silversmiths reacting against the preaching of Paul is calmed down by an official who tells the silversmiths to take their quarrel to the proconsul and that any remaining issues should be discussed at a regular assembly meeting.

26 For an interesting parallel see Luc. De mort. Peregr. 15, where Proteus is brought before the Parian assembly on charges of murder but escapes the trial altogether by making a generous donation for which he is

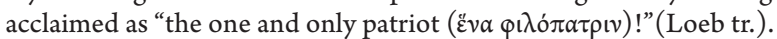

27 Tr. B. P. Reardon, 'Chariton: Chaireas and Callirhoe', in: B. P. Reardon (ed.), Collected Ancient Greek Novels (Berkeley 1989), 17-125.

28 The use of $\varphi \imath \lambda o ́ \pi \alpha \tau \rho \iota \varsigma$ in Aphrodisian inscriptions has been noted by C. Ruiz-Montero, 'Caritón de Afrodisias y el Mundo Real', in: P. Liviabella Furiani and A. Scarcella (eds.), Piccolo mondo antico (Napoli

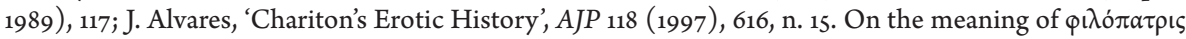
in inscriptions see L. Robert, Hellenica 13 (1965), 215. On $\mu \varepsilon ́ \gamma \alpha \varsigma$ see L. Robert and J. Robert, La Carie: histoire et géographie historique avec le recueil des inscriptions antiques. Tome II: Le plateau de Tabai et ses environs (Paris 1954), 101, n. 1.

29 IAph 2007 12.308.6, with R. R. R. Smith, Roman Portrait Statuary from Aphrodisias (Mainz am Rhein 2006), 22; IAph 2007 11.16.8, with J. Reynolds, 'Honouring Benefactors at Aphrodisias: a New Inscription', in: C. Roueché and R. R. R. Smith (eds.), Aphrodisias Papers 3 (Ann Arbor 1996), 124. Tilg, Chariton (above, n. 18), 52-59, tentatively suggests that the Athenagoras attested in IAph2007 13.302ii (first or second century A.D.) can be identified as the employer of Chariton mentioned in the novel's opening lines. 
and he shall have a share of the spoils as his dowry!" The assembly acclaimed his words. "The

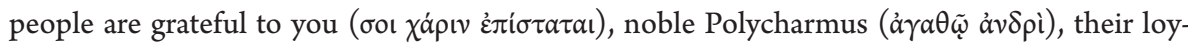

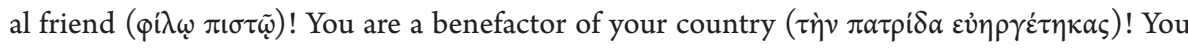
are worthy ( $\ddot{\alpha} \xi \circ \varsigma)$ of Hermocrates and Chaireas!” After this Chaereas spoke again. “The three hundred men here," he said, "Greeks, my brave (å $v \delta \varepsilon \tilde{\varepsilon} o v)$ company - I ask you to grant them citizenship!” Again the assembly cried, “They are worthy ( $a \xi$ เo ) to be citizens of Syracuse - let us have that voted!” (8.8.12-14) $)^{31}$

The vocabulary of this passage closely follows the stereotypical language of honorific decrees stressing the gratitude of the community and the benevolence and loyalty displayed by the honorand. An Aphrodisian honorific decree from the first or second-century A.D., for example, commends a certain Attinas Meliton for acting "be-

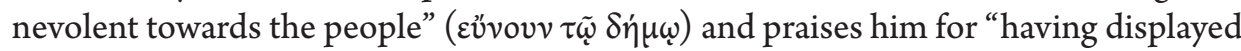

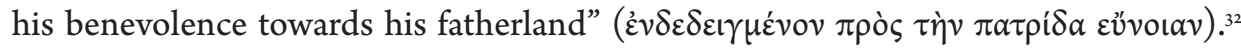

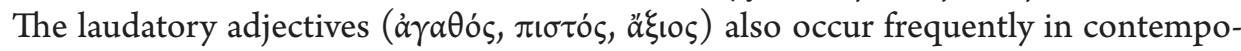
rary inscriptions, as we already saw above in the inscription for Athenagoras son of

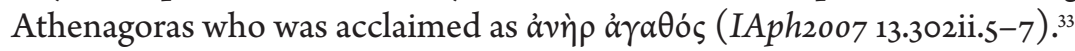

At the level of the key function, that is, the communication between author and reader, this honorific discourse evokes the politics of munificence that pervaded civic life in the imperial period. ${ }^{34}$ It is significant that both the beginning and end of the narrative are marked by meetings of the assembly and honorific acclamations. ${ }^{35}$ In the first ekklesia scene Hermocrates' approval of the marriage between the protagonists is presented as a gift to the community greatly desired by the people and granted out of love for his country. In this way, the first obstacle in Chariton's love story, the political rivalry between the fathers of Chaireas and Callirhoe, is overcome through an act of munificence that reasserts the primacy of the public good over personal interest. In the final assembly scene Polycharmus is honoured as a benefactor of his country for securing the safe return of the city's favourite couple. Chariton's use of a well-known civic discourse centred on munificence and honour politicizes the erotic transforming a private romance into a matter of the highest public importance. ${ }^{36}$ The two ekklesia

31 Tr. Reardon, 'Chariton' (above, n. 27).

32 IAph2007 12.206.16-17, my tr.

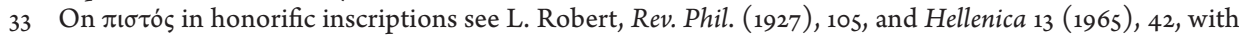
n. 2 .

34 On the concepts of 'key function' and 'argument function' see $\varnothing$. Andersen, 'Myth, paradigm and 'spatial form' in the Iliad', in: J.M. Bremer, I.J. F. de Jong and J. Kalff (eds.), Homer: Beyond Oral Poetry: Recent Trends in Homeric Interpretation (Amsterdam 1987), 1-13; I.J. F. de Jong, 'Homer and Narratology', in: I. Morris and B. B. Powell (eds.), A New Companion to Homer (Leiden 1997), 305-325, at 309, and Idem, Narratology and Classics (Oxford 2014), 34-37.

35 A third assembly meeting (3.4.3-18) similarly signifies an important turning point in the narrative, as the people of Syracuse discover that Callirhoe is still alive.

36 On the novel's general tendency to politicize the erotic see J. Alvares, 'Some Political and Ideological Dimensions in Chariton's Chaereas and Callirhoe', CJ 97 (2001-2002), 114; Smith, Greek Identity (above, n. 20), 222-225; Whitmarsh, Narrative (above, n. 22), 32-40, 146-147. The people's emotional involvement in Callirhoe's marriage, second marriage (3.2.15-17) and funeral (1.6.2-5) seems to be a reflection of 
scenes marking the onset and conclusion of the novel thus emphasise the extraordinary nature of Chariton's love story.

The strong presence of a real-life civic discourse also suggests that Chariton's assembly scenes can improve our understanding of assembly politics in the imperial Greek city. The way in which the rhetoric of honour was used by the characters in the narrative could tell us something about its use in contemporary politics. In the first ekklesia scene the people's request for Hermocrates' consent to the marriage is preceded by popular acclamations stressing his virtuous character. In discourse-theoretical terms this can be described as an instance of hailing or interpellation, since the acclamations implicitly pressure Hermocrates to conduct himself according to his publicly constructed identity. ${ }^{37}$ By responding to the acclamations Hermocrates becomes interpellated with the identity of a virtuous citizen, a 'subject position' to which a certain set of behavioural expectations was attached. ${ }^{8}$ In the rhetoric of honour a good citizen is someone who displays virtues that were essentially civic in character, that is, virtues which were aimed at the common good..$^{39}$ If Hermocrates wanted to live up to his status as a virtuous citizen, he needed to set aside his political rivalry with the father of Chaireas and give his consent to the marriage. The popular acclamations for Hermocrates indeed achieved their desired effect, as the narrator tells us that Hermocrates "loved his country and could not refuse what it asked" (1.1.12).

The ability of the people to make strategic use of acclamations in order to gain Hermocrates' approval depends on the ideology of reciprocity involved in the exchange of gifts for honours. ${ }^{40}$ In the final assembly scene this ideology is clearly visible when Chaireas explicitly presents his public expression of gratitude and counteracts of generosity as compensation for the goodwill and loyalty displayed by his friend Polycharmus. Particularly revealing of the ideology of reciprocity are the so-called 'proleptic honours' granted by cities as compensation for acts of munificence that had not yet been undertaken or even promised. Although presented as recompenses in advance, these honours de facto functioned as gifts that needed to be reciprocated. ${ }^{41}$

contemporary social realities, as can be seen from the so-called consolation decrees that were issued by the city on the occasion of the death of a citizen with the aim of honouring the deceased and consoling his family. See P. Herrmann, 'Zwei Inschriften aus Kaunos und Baba Dag', Opuscula Atheniensia 10 (1971), 36-40; J. H. M. Strubbe, 'Epigrams and Consolation Decrees for Deceased Youths', L'antiquité classique 67 (1998), 45-75.

On the process of interpellation see L. Althusser, 'Idéologie et appareils idéologiques d'État. (Notes pour une recherche)', in: Positions (1964-1975) (Paris 1976), 110-111.

38 On subject positions in discursive systems see E. Laclau and C. Mouffe, Hegemony and Socialist Strategy: towards a Radical Democratic Politics (London 1985), 114-115.

39 For civic ideology and honorific practices in the Hellenistic period see J. Ma, Statues and Cities: Honorific Portraits and Civic Identity in the Hellenistic World (Oxford 2013).

40 On euergetism and reciprocity see Zuiderhoek, Politics of Munificence (above, n. 2), 113-154; M. Domingo Gygax, 'Gift-Giving and Power Relationships in Greek Social Praxis and Public Discourse', in: M. L. Satlow (ed.), The Gift in Antiquity (Hoboken 2013), 45-60.

41 M. Domingo Gygax, 'Proleptic Honours in Greek Euergetism', Chiron 39 (2009), 163-191. See also O. M. van Nijf, The Civic World of Professional Associations in the Roman East (Amsterdam 1997), 111-113, who calls attention to the anticipatory honouring of professional associations who tried to establish a beneficial relation with a rich citizen. 
The people's acclamation of Hermocrates as a great general draws attention to his status as the one who famously defeated the Athenian fleet. Nevertheless, it is his assent to the marriage of Chaireas and Callirhoe that would be "the very first of his trophies" $(\pi \rho \tilde{\omega} \tau o v \tau \tilde{\omega} \nu \tau \rho o \pi \alpha i \omega v, 1.1 .11) .{ }^{42}$ If Hermocrates was to reaffirm his status, he had to let the people's wish prevail over his political rivalry with Ariston. Here, the proleptic aspect of the popular acclamation thus predominates over its function as a reward for past behaviour.

This first analysis shows how practices of reciprocity that guided public behaviour and speech were expressed and maintained through the rhetoric of honour. In this respect, the assemblies in Chariton's novel do not seem to be that far removed from Josiah Ober's assessment of democratic Athens where "[a]n ongoing dialogue between eloquent elite speakers eager for influence and honors on the one hand, and highly vocal and responsive mass audiences concerned with preserving their equal high standing as citizens on the other, served to define and to justify to each side the terms of a fair bargain." ${ }^{43}$ Although in the imperial period the democratic ideology of isonomia made way for more hierarchical notions of society, public communication in the assembly continued to define the relation between elites and their communities in terms of reciprocity. ${ }^{44}$ Furthermore, the first ekklesia scene indicates that the demos could put the discourse of honour to rhetorical use reminding a leading citizen of his responsibility for generosity, signalling that a violation of this responsibility would result in the deterioration of his reputation.

In order to further examine the role of the rhetoric of honour in the assemblies of the imperial period we now leave behind the world of the romance novel and turn to a speech of Dio of Prusa.

\section{Dio's Euboicus}

The seventh oration of Dio Chrysostom, better known as the Euboicus, contains an extensive and vivid description of an assembly meeting taking place in an unspecified Euboean city (22-63). ${ }^{45}$ This assembly scene is framed by a fascinating and supposed-

42 Tr. Smith, Greek Identity (above, n. 20), 58.

43 J. Ober, 'Mass and Elite Revisited', in R. Evans (ed.), Mass and Elite in the Greek and Roman World (forthcoming), 4-5.

44 On the process of hierarchisation in the imperial Greek city see van Nijf, Civic World (above, n. 41); Zuiderhoek, Politics of Munificence (above, n. 2), 14, 69, 119; Heller, 'La cité grecque' (above, n. 8).

45 Possibly Carystus, see C. P. Jones, The Roman World of Dio Chrysostom (Cambridge, Mass./London 1978), 58. The exact date of delivery is unknown but the speech appears to be post-exilic (i. e. after 96 A.D.). It is often assumed that the oration is from late in Dio's life on account of the apologetic remarks at the beginning of the speech see ibid., 135; T. Bekker-Nielsen, The Urban Life and Local Politics in Roman Bithynia (Aarhus 2008) 136, 145. Yet, D. A. Russell, Dio Chrysostom. Orations VII, XII, XXXVI (Cambridge 1992), 110 , rightly points out that this is not necessarily the case. The place of delivery is also uncertain although some passages in the second part of the oration, which may well have been a separate speech altogether, suggest an audience in Rome see P. A. Brunt, 'Aspects of the Social Thought of Dio Chrysostom and the Stoics', PCPS 19 (1973), 16-17; Russell, Dio Chrysostom (above, n. 45), 13, 139-140, 146. Yet, other passages 
ly autobiographical story $(1-80)$ about an encounter Dio had with a poor countryman who generously accommodates him after Dio was shipwrecked at the "hollows of Euboea.' It is produced in the text not by Dio in propria persona but through the mouth of a secondary narrator, the rustic figuring in the frame narrative, telling Dio of one of his scarce visits to the town nearby ${ }^{46}$ Although the ekklesia scene thus purports to be a description of an actual assembly meeting taking place in the recent past, its authenticity is complicated by the narrative's idyllic pastoral setting, its topoi and Homeric allusions, and New Comedy plot-structure: all elements more commonly associated with the fictional world of the novel. ${ }^{47}$ Dio himself presents his Euboean tale as an "illustration" ( $\pi \alpha \rho \alpha \dot{\delta} \delta \varepsilon \gamma \mu \alpha, 81)$ of the fact that the poor are just as capable (or even more capable) of "living a seemly and natural life" as the rich. The assembly scene which follows after an ecphrasis of rural Euboea (10-20) is inserted into the main narrative in order to provide a contrast ( $\sigma \dot{v} \gamma \kappa \rho l \sigma \iota \varsigma$ ) between urban life and the idealized existence of the countryman..$^{48}$ In spite of the Euboicus' literary playfulness John Ma has persuasively argued, on the basis of inscriptional and papyrological parallels, that the ekklesia scene constitutes a fairly accurate representation of historical realities. ${ }^{49}$ The most evident indication of this is the honorific proposal presented to and passed by the assembly at very end of the meeting: ${ }^{\circ}$

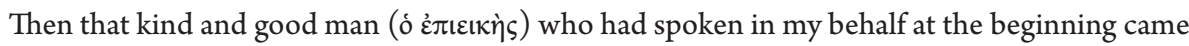
forward and said, 'I move, sirs, that we invite this man to dine in the town-hall. If he had saved

suggest that Dio's native Prusa was the decor for another version of the speech see J. L. Moles, 'Dio Chrysostom, Greece, and Rome', in D. Innes, H. Hine and C. Pelling (eds.), Ethics and Rhetoric (Oxford 1995), 177.

46 This setup resembles some well-known assembly scenes from Attic drama and comedy. See G. Highet, 'The Huntsman and the Castaway', GRBS 14 (1973), 37-39, referring to Ar. Eq. 624-682, Eur. Or. 852-956 and Ar. Eccl. 395-457.

47 For similarities with New Comedy and the novels see e.g. Highet, 'Huntsman' (above, n. 46), 35-40; F. Jouan, 'Les thèmes romanesques dans l'Euboïcos de Dion Chrysostome', REG 90 (1977), 38-46; S. Swain, 'Dio and Lucian', in: J. R. Morgan and R. Stoneman (eds.), Greek Fiction: the Greek Novel in Context (London 1994), 166-172; Moles, 'Dio Chrysostom' (above, n. 45), 177-18o. On the literary play with shipwreck stories and 'Gastmahlszenen' see A. M. Milazzo, Dimensione retorica e realtà politica: Dione di Prusa nelle orazioni III, V, VII, VIII (Olms 2007), 163-226.

48 On the Euboicus as a combination of different rhetorical exercises see G. Anderson, The Second Sophistic: a Cultural Phenomenon in the Roman Empire (London 1993), 52-53.

49 J. Ma, 'Public Speech and the Community in the Euboicus', in Swain, Dio Chrysostom (above, n. 12), 108-124, citing to Syll. ${ }^{3} 898$, P.Ryl. II 66, I.Mylasa 515 and IG XII.9.11 (all second or third century A.D.). For similar views see Zuiderhoek, 'Political Sociology' (above, n. 10), 423-424; N. Vujčić, 'Greek Popular Assemblies in the Imperial Period and the Discourses of Dio of Prusa', EA 42 (2009), 165; O. M. van Nijf, 'Affective Politics: the Emotional Regime in the Imperial Greek City', in: A. Chaniotis and P. Ducrey (eds.), Unveiling Emotions II (Stuttgart 2013), 358-360. On the historicity of the Euboicus in general see J.-M. Bertrand, 'Le Chasseur dans la Ville', in: M.-F. Baslez, P. Hoffmann and M. Trédé (eds.), Le monde du roman grec (Paris 1992), 85-92; D. Engster, 'Fiktion oder Realität? Dions Euboikos Logos in der althistorischen Forschungsdiskussion seit Eduard Meyer', in: A. Lehmann et al. (eds.), Armut - Arbeit - Menschenwürde. Die Euböische Rede des Dion von Prusa (Tübingen 2012), 143-165.

50 Jones, Roman World (above, n. 45), 60, notes that the proposal is presented to the assembly without prior discussion in the council, a practice Dio elsewhere condemns as demagogic (Or. 56.10). Nevertheless, it does not seem to have been exceptional in Prusa, as can be seen from I.Prusa ad Olymp. 14-15, 26-31, and 1006-1011. 
one of our townsfolk in battle by covering him with his shield, would he not have received many large gifts? But now, when he has saved two citizens, and perhaps others who are not here, is

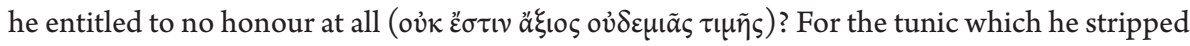
from his daughter and gave to his fellow-townsman in distress, let the city give him a tunic and

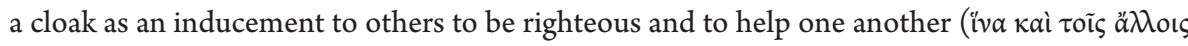

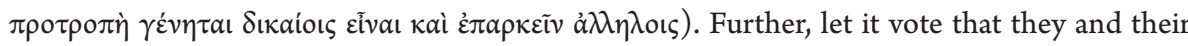
children have the use of the farm free from molestation, and that the man himself be given one hundred drachmas for equipment; and as for this money, I offer it out of my own pocket on behalf of the city (i் $\dot{\varepsilon} \rho \tau \tilde{\eta} \varsigma \pi \hat{\lambda} \lambda \varepsilon \omega \varsigma)$. "For this he was applauded and the motion was carried $(60-62)$.

The proposal clearly fits with what we know about the honorific practices of the imperial period: a public dinner at the Prytaneion was a common reward for benefactors and promises to supply money "on behalf of the city" feature prominently in contemporary inscriptions. ${ }^{51}$ The rhetorical question "is he entitled to no honour at all?" draws attention to the community's social obligation to reward the rustic and reveals the compulsion towards reciprocity we also encountered in Chariton's assembly scenes. Furthermore, the orator's purpose clause motivating the reward for the countryman as an incentive for others closely resembles the 'hortatory intention' clause of honorific decrees which explicitly states that the goal of the grant of honours is to solicit further benefactions and presents the inscription as a visual reminder of the community's sense of reciprocity (i.e. its willingness to recompense benefactors with appropriate honours). ${ }^{52}$ At first sight, the Euboicus thus provides us with a rather straightforward, even stereotypical account of a Greek city honouring one of its benefactors. However, on closer examination there is much more to this ekklesia scene than its conclusion suggests.

Although the assembly ends with the rustic being rewarded as a benefactor of the city, the story starts off on a very different note. One day, the countryman tells Dio, a man from the city nearby came to his hut demanding rent for the use of polis land. Unable to provide the money, the rustic is brought before the assembly where he is charged with illegally squatting on public land. The assembly meeting is marked by a lively debate between two rival orators competing for popular approval. The first orator that comes forward claims that the countryman and his neighbour "live free from taxes and public services as though they were benefactors of the city" (á $\tau \varepsilon \lambda \varepsilon i \varsigma$

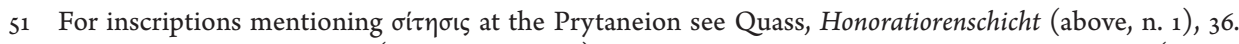

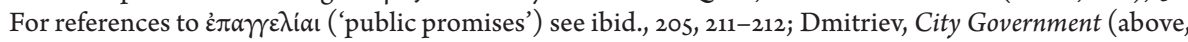
n. 9), 39-44.

52 The hortative clause has been noted by Jones, Roman World (above, n. 45), 61, and Russell, Dio Chrysostom (above, n. 45), 126. On the hortatory intention clause see A.S. Henry, 'The Hortatory Intention in Athenian State Decrees', ZPE 112 (1996), 105-119; N. Luraghi, 'The Demos as Narrator: Public Honours and the Construction of Future and Past', in: H.-J. Gehrke, N. Luraghi and L. Foxhall (eds.), Intentional History: Spinning Time in Ancient Greece (Stuttgart 2010), 247-264; S. D. Lambert, 'What Was the Point of Inscribed Honorific Decrees in Classical Athens?', in: S. D. Lambert (ed.), Sociable Man: Essays on Ancient Greek Social Behaviour in Honour of Nick Fisher (Swansea 2011), 193-207. 


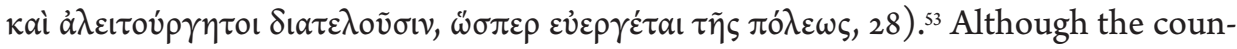
trymen are wealthy and live off public land capable of yielding enough grain for a distribution of three Attic measures per citizen, they "have never performed any public

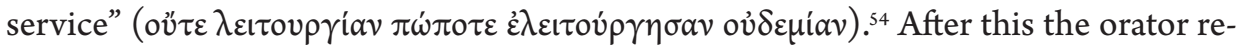
bukes the rustic for his hubris and mockery, claiming that his poor appearance is part of a ploy to hide his wealth from the people. The invective culminates in a comparison to king Nauplius, famous for shipwrecking part of the fleet returning from Troy, as the rhetor accuses the countryman of leading a gang of wreckers who profit from leading others to their ruin (31-32). Incited by the orator's rhetoric the crowd "became very

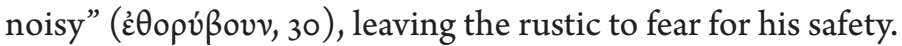

Then a second orator takes the floor arguing that the countrymen have actually done the city a favour by cultivating the waste land. It has been suggested that this second orator serves as an alter ego for Dio on account of the similarities in their views on the city and the philosophical tone of their argumentation. ${ }^{55}$ This seems to be confirmed by the rustic's characterisation of the second speaker as a "good kindly

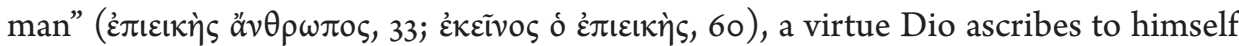
at several points in his political career in Prusa. ${ }^{56}$ In contrast with the first speaker, the moderate orator has a calming effect on the audience, as he speaks to them "in a quiet tone" ( $\tau \tilde{\eta} \varphi \omega \nu \tilde{\eta} \pi \rho \alpha \dot{\alpha} \omega \varsigma, 33)$. From honorific epigraphy in which the epithets $\pi \rho \tilde{a} o \varsigma$

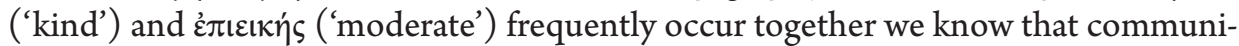
ties sought to promote these virtues in their politicians. ${ }^{57}$ However, even though Dio's alter ego displays these virtues, he still fails to defeat his rival in their rhetorical contest. The assembly meeting has come to a deadlock until there is a final twist to the story.

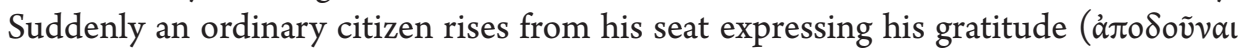
$\lambda o ́ \gamma \omega \chi \alpha$ $\rho \imath, 54)$ towards the countryman and telling the audience how he and another citizen were saved by him after having suffered shipwreck (54-58)..$^{8}$ After this testimony the people's anger turns into praise (غ่лńvovv, 59) and the second orator quickly steps up to introduce the honorific proposal.

Dio's ekklesia scene thus takes the audience through a compelling emotional trajectory that ends in relief and joy when the rustic is not dragged off to prison, as the first orator had suggested, but honoured as a benefactor of the city instead. Yet, the countryman is as confused by the people's acclaim as he was by their thorybos (62-63). It seems therefore that Dio has deliberately chosen this naive rustic as the narrator of his assembly scene in order to denaturalise and perhaps even question his audience's urban perspective on assembly politics and civic honours. When the countryman first

For $\alpha \dot{\alpha} \varepsilon^{\prime} \varepsilon_{\varepsilon} \alpha$ as a reward for benefactors see Quass, Honoratiorenschicht (above, n. 1), 36, n. 96. As Russell, Dio Chrysostom (above, n. 45), 118, observes this is "a quite absurd prediction of yield."

Bekker-Nielsen, Urban Life (above, n. 45), 138-140.

See Or. 44.2, 49.1, 50.1 and 50.10

L. Robert, Hellenica IV (1948), 15-18, and Hellenica XIII (1965), 223-224; C. Panagopoulos, 'Vocabulaire et mentalité dans les Moralia de Plutarque', $\mathrm{DHA}_{3}$ (1977), 218.

An interesting parallel can be found in Chariton's novel where the testimony of a local fisherman thwarts the tomb robber Theron's ploy to deceive the Syracusan assembly (3.4.11). 
enters the theatre, he observes how the people sometimes shouted "kindly and joy-

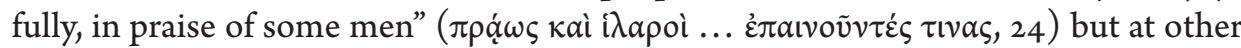

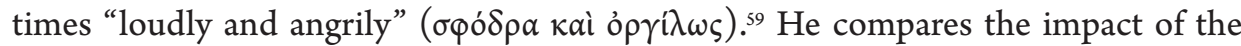
people's angry shouting to a "tidal wave or thunder-storm" (25) that frightens and interrupts the speakers in the assembly. The rustic's story thus suggests that popular anger was just as effective an instrument for influencing public speakers as the acclamations we encountered in Chariton's assembly scenes. If it were not for Dio's own political speeches addressed to the assembly of his native Prusa, the effects of thorybos on elite speakers could be dismissed as an exaggeration or a second sophistic echo of classical democratic Athens. ${ }^{60}$ Dio's own orations contain several references to ecclesiastic thorybos and are often preceded by introductions in which the orator urges his fellow citizens to grant him an attentive hearing. ${ }^{61}$ In the $48^{\text {th }}$ oration Dio even criticizes the assembly for their angry denunciation of persons whom they had only recently

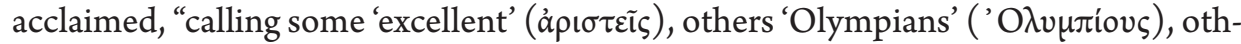

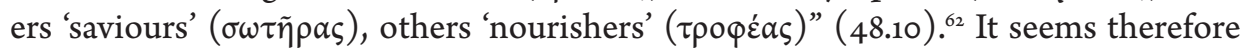
no coincidence that the countryman's account similarly highlights the volatility of popular opinion.

Nevertheless, although acclamations and thorybos are opposites in the range of possible audience responses, they can be regarded as two sides of the same coin. The demagogue is able to stir up the demos by falsely depicting the rustic as a self-serving and arrogant rich man who avoids liturgies and seeks to profit at the expense of the community. This stereotypical depiction of the bad citizen is the mirror image of the generous benefactor that features so prominently in the epigraphic record. The rhetoric of honour and the demagogue's invective are both grounded in an ideology that expected elites to use their private wealth for the benefit of the community. From another episode in Dio's own political career we know that he had experienced the dangers of being perceived of as violating these expectations first-hand. In the $46^{\text {th }}$ oration, delivered at the time of a local grain shortage, the orator claims that a mob suspecting him of withholding grain from the market in order to drive up the price almost burned down his house during a food riot. In light of this information it is tempting to interpret the Euboean assembly scene as a criticism of contemporary assembly

59 Tr. Ma, 'Public Speech' (above, n. 49), 111. Russell, Dio Chrysostom (above, n. 45), 117, observes "غ̇ंaเvoṽ-

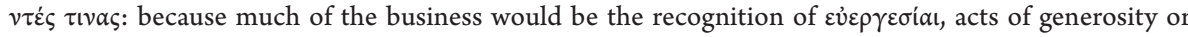
other services, by honorific decrees."

60 On thorybos in the assembly of democratic Athens see J. Tacon, 'Ecclesiastic Thorubos: Interventions, Interruptions and Popular Involvement in the Athenian Assembly', G\&'R 48 (2001), 173-192; R. Thomas, "And you, the Demos, Made an Uproar': Performance, Mass Audiences and Text in the Athenian Democracy', in: A. Lardinois, J. Blok and M. G. M. van der Poel (eds.), Sacred Words: Orality, Literacy and Religion (Leiden 2011), 161-187. On thorybos in the imperial period see M. Korenjak, Publikum und Redner. Ihre Interaktion in der sophistischen Rhetorik der Kaserzeit (Munich 2000), 78-79.

61 See Or 38.6, 46.10, 46.10 and 48.16 .

62 Loeb tr. For a discussion of these titles and their ideological significance see Heller, 'La cité grecque' (above, n. 8), 364-368. 
politics. ${ }^{63}$ For the primary narratees, in the know about the rustic's simple lifestyle and hospitable reception of the shipwrecked Dio, it is painfully clear how easy it is for a demagogue to manipulate his audience by capitalizing on collective ideas about the proper use of elite wealth. Dio's use of a naive rustic as a secondary narrator supplies his criticism with an air of truthfulness and natural authority increasing its impact on the audience.

Whereas Chariton's novel only showed how the people rewarded and encouraged good citizenship through public praise, the Euboean assembly scene also demonstrates the assembly's response to bad citizenship. The topoi employed in the demagogue's invective of the rustic indicate that citizenship was defined both positively, through the rhetoric of honour, and negatively, through a discourse on the bad citizen. ${ }^{64}$ According to Matthew Christ, one of the hallmarks of Athenian democracy was "the way it engendered public discourse in a range of civic contexts [which] provided diverse opportunities for Athenians to articulate and promulgate civic norms, including what constituted good citizenship and its opposite." ${ }^{\text {6s }}$ Based on Dio's Euboicus it could be argued that the assembly in the imperial period still served as a forum for the articulation of civic norms and, more importantly, as a place where violations of these norms were identified and monitored for compliance through public speech. ${ }^{66}$ It seems therefore that even though civic ideology in the imperial period was far less egalitarian than in democratic Athens, it was still able to constrain elites within communitarian norms. ${ }^{67}$

We will now turn to the assembly scene of John Chrysostom from which it appears that three centuries later the rhetoric of honour was still very much alive.

\section{John Chrysostom's De inani gloria ${ }^{68}$}

Our final assembly scene can be found in John Chrysostom's De inani gloria et de educandis liberis, a sermon on the evils of $\kappa \mathcal{E} v 0 \delta$ o $\xi^{\prime} \alpha$ ('vainglory') and the education of the young, delivered to a (primarily) Christian audience in Antioch at the end of the

63 On the Euboicus as a political testament containing "the hopes and frustrations" of Dio's local career see Bekker-Nielsen, Urban Life (above, n. 45), 36, 140. A recurring problem in Dio's dealings with the Prusan assembly was the construction project for which he was responsible (cf. Or. 40, 45 and 47). From the correspondence between Pliny and Trajan (Ep. 10.81) we know that he was unsuccessfully prosecuted by one of his fellow citizens for financial misconduct in a building project.

64 Both discourses can be traced back to classical Athens. Cf. Ober, Mass and Elite (above, n. 4), 170-174, 205-214; M. Christ, The Bad Citizen in Classical Athens (Cambridge 2006).

65 Christ, Bad Citizen (above, n. 64), 42.

66 Not unlike the discursive restraints placed on leading citizens in democratic Athens. Cf. Ober, Mass and Elite (above, n. 4), 332-339.

67 On the continuity of communitarian discourse in the Hellenistic period see Ma, Statues and Cities (above, n. 39), 11, 238, 297.

68 Citations refer to the Greek text of A.-M. Malingrey, Jean Chrysostome. Sur la vaine gloire et l'éducation des enfants. Introduction, texte critique, traduction et notes (Paris 1972). Tr. M.L.W. Laistner, Christianity and Pagan Culture in the Later Roman Empire (Ithaca, N. Y. 1978). 
fourth century. ${ }^{69}$ The transition from the oration's first part on vainglory $(1-15)$ to the larger second part containing outlines for an educational programme (16-90) is made by the claim that the upbringing of the young was to blame for the prevailing propensity to vainglory. John's elaborate introduction on vainglory can thus be seen as a $\pi \rho \circ \lambda \alpha \lambda i ́ a$, a relatively autonomous and rhetorical prologue that is nevertheless meaningfully linked to the main body of the text. ${ }^{70}$ The assembly scene $\left(\mathrm{SC}_{188}, 74-78\right)$ is inserted as an example from "the pagan world about us" (SC 188, 74) revealing the true nature of vainglory:

The theatre is filling up, and all the people are sitting aloft presenting a splendid sight and composed of numberless faces, so that many times the very rafters and roof above are hidden by human bodies. You can see neither tiles nor stones, but all is men's bodies and faces. Then, as

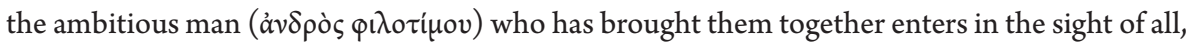
they stand up and as from a single mouth cry out. All with one voice call him protector and ruler

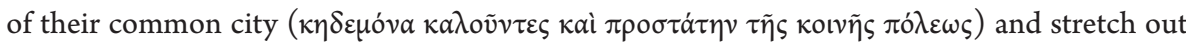
their hands in salutation. Next, betweenwhiles they liken him to the greatest of rivers, compar-

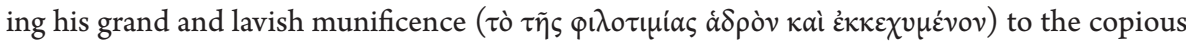
waters of the Nile; and they call him the Nile of gifts. Others, flattering him still more and thinking the simile of the Nile too mean, reject rivers and seas; and they instance the Ocean and say

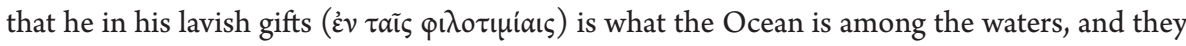
leave not a word of praise unsaid.

The assembly scene thus portrays the glorious entry of the benefactor and the superlative honours bestowed on him. Although Louis Robert already called attention to the presence of honorific titles in this Christian text from the late fourth century, the only extended treatment of its relation to the euergetic system has been made by Geert Roskam. ${ }^{71}$ Nevertheless, John's initial description of the honorific process seems

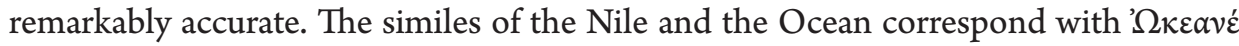
acclamations attested in Egyptian papyri dating to the late third and fourth century

69 With the exception of F. Schulte, S. Joannis Chr. de inani gloria et de educandis liberis (Münster 1914), scholarship sees Antioch as the setting of the speech which places its date between 378 and 398 A.D. For an overview see Malingrey, Jean Chrysostome (above, n. 68), 41-47; Laistner, Christianity (above, n. 68), 78-84; M. Gärtner, Die Familienerziehung in der Alten Kirche: eine Untersuchung über die ersten vier Jahrhunderte des Christentums mit einer Übersetzung und einem Kommentar zu der Schrift des Johannes Chrysostomus über Geltungssucht und Kindererziehung (Cologne 1985), 197-200. On the possibility of pagan observers in the audience see W. Mayer, 'The Audience(s) for Patristic Social Teaching: a Case Study', in: J. Leemans, B. Matz and J. Verstraeten (eds.), Reading Patristic Texts on Social Ethics: Issues and Challenges for Twenty-First-Century Christian Social Thought (Washington 2011), 85-100.

70 G. Roskam, 'John Chrysostom on Pagan Euergetism: a Reading of the First Part of De inani gloria et de educandis liberis', SEJG 53 (2014), 147-169.

71 Roskam, 'John Chrysostom' (above, n. 70), 147-169. For shorter discussions see L. Robert, 'Sur une mon-

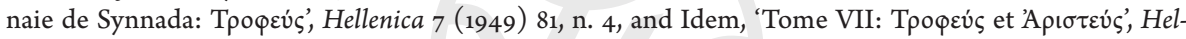
lenica 11/12 (1960), 571, n. 1; P. Brown, Power and Persuasion in Late Antiquity: towards a Christian Empire (Madison 1992), 83; and van Nijf, Civic World (above, n. 41), 210; van Nijf and Alston, Political Culture (above, n. 12), 14; Zuiderhoek, Politics of Munificence (above, n. 2), 127-128. 
A. D. ${ }^{72}$ It is generally believed that these ' $\Omega \kappa \varepsilon \alpha v \varepsilon$ exclamations are laudatory epithets comparing the recipient to the Ocean. ${ }^{73}$ In the assembly scene the tertium comparationis is made explicit: the generosity of the honour-loving man resembles the boundlessness of the Nile and Ocean. On account of this extraordinary liberality the benefactor is acclaimed as $\kappa \eta \delta \varepsilon \mu \omega$ ' ('protector') and $\pi \rho \circ \sigma \tau \alpha \dot{\tau} \eta\rceil \varsigma$ ('leader') of the city, honorific titles that stress the benefactor's concern for the well-being of the community. ${ }^{74}$

The elites' obligation to care for and protect the interests of their cities was often couched in terms that stressed the affectionate and familial relation between politicians and their communities. ${ }^{75} \mathrm{~A}$ papyrus recording the popular acclamations during an Egyptian town meeting, for example, describes how a certain Dioscorus was honoured through ' $\Omega \kappa \varepsilon a v \varepsilon$-acclamations and receives the laudatory epithets $\kappa \eta \delta \varepsilon \mu \omega \nu$ and $\varphi$ i states that the true politician "loves ... the State and is careful of the public welfare" ( Chariton's novel explains that Hermocrates' approval of the marriage of Chaireas and Callirhoe was motivated by the love Hermocrates felt for his country (1.1.12). Later on in the novel, the same rhetoric of honour finds an unlikely recipient when Dionysius, Miletus' most important citizen, expresses his gratitude to the slave Phocas for

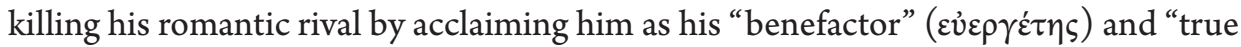

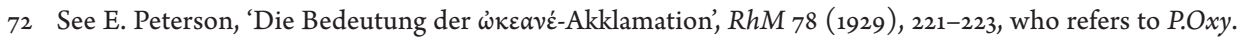
I 41, P.Oxy. X 1305, P.Oxy. XII 1413, and SPP XX, 58 Col. I 8. T. Kruse, 'The Magistrate and the Ocean: Acclamations and Ritualised Communication in Town Gatherings in Roman Egypt', in: E. Stavrianopoulou (ed.), Ritual and Communication in the Graeco-Roman World (Liège 2006), 306, adds P.Oxy. XXIV, 2407 and 2417. On civic politics in Egypt see L. E. Tacoma, 'The Councillor's Dilemma. Political Culture in Third-Century Roman Egypt', in: van Nijf and Alston, Political Culture (above, n. 12), 243-261.

73 T. Klauser, 'Akklamation', $R A C_{1}$ (1950), 216-233, at 223; Laistner, Christianity (above, n. 68), 135; Roskam, 'John Chrysostom' (above, n. 70), 152. For a different interpretation see Kruse, 'Magistrate' (above, n. 72), 305-309, who argues that in the papyri the honorand is not called or compared to the Ocean and that ' $\aleph \varepsilon \alpha v \varepsilon$-exclamations only stress the boundlessness of the actual acclamations that follow. He also argues that the passage in John's assembly scene merely states that the benefactor was compared ( $\sigma v \gamma \kappa \rho i v o v \tau \varepsilon \varsigma$, SC 188,78$)$ to the Nile and the Ocean, not that he was called so through acclamation. On this account it

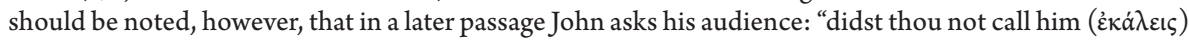
Nile and Ocean?" (SC 188, 84).

74 See Panagopoulos, 'Vocabulaire' (above, n. 57), 216, citing Plut. Mor. 796E, 812B, 823A, and 823C. For references to inscriptions see Roskam, 'John Chrysostom' (above, n. 70), 151, n. 16. Cf. also Dio 50.7 (Loeb

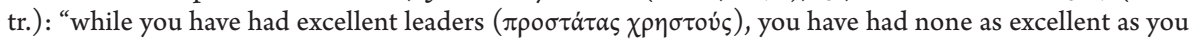

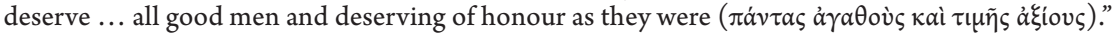

75 This is most clearly visible in the use of kinship metaphors in honorific epigraphy see C. Roueché, 'A New

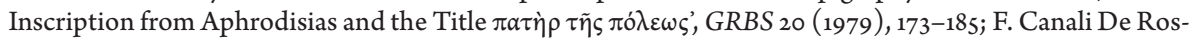
si, Filius Publicus: viòs $\tau \tilde{\eta} \varsigma \pi o ́ d \varepsilon \omega \varsigma$ e titoli affini in iscrizioni greche di età imperiale. Studi sul vocabolario dell'e-

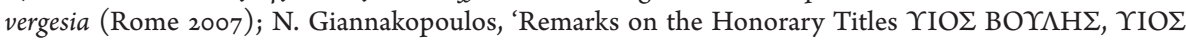
$\triangle \mathrm{HMO}$ and $\Upsilon \mathrm{IO} \Sigma \Pi \mathrm{O} \Lambda \mathrm{E} \Omega \Sigma$ ', in A. Rizakes and F. Camia (eds.), Pathways to Power: Civic Elites in the Eastern Part of the Roman Empire (Athens 2008), 251-268. On affective terminology in local politics see Panagopoulos, 'Vocabulaire' (above, n. 57), 214-216; van Nijf, 'Affective Politics' (above, n. 49), 359-365.

76 P.Oxy. I 41 (late III - early IV), with M. Blume, 'À propos de P. Oxy. I, 41. Des acclamations en l'honneur d'un prytane confrontées aux témoignages épigraphiques du reste de l'Empire', in: L. Criscuolo and G. Geraci (eds.), Egitto e storia antica. Atti del Colloquio internazionale. Bologna, 31.8-2.9.1987 (Bologna 1989), 271-290.

77 Loeb tr. 


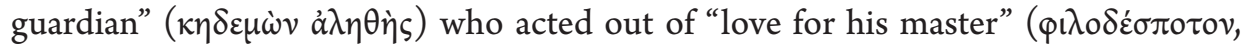

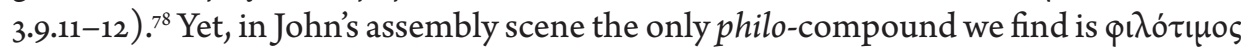
which is used to characterize the otherwise nameless benefactor.

The fact that John's benefactor is driven only by his desire for civic honours has everything to do with the text's rhetorical agenda: to unmask pagan $\varphi i \lambda o \tau \mu \mu i \alpha$ as an instance of $\kappa \varepsilon v o \delta o \xi i \alpha$. After depicting the dramatic entrance of the honour-loving man John quickly remarks that "the face of vainglory is brilliant" ( $\lambda \alpha \mu \pi \rho \dot{\alpha} \tau \tilde{\eta} \varsigma \kappa \varepsilon v o \delta o \xi i a \varsigma ~ \dot{\eta}$ ö $\psi(\varsigma$, SC 188, 78), thus recalling his previous description of the people gathered in the theatre as a "splendid sight" (ő $\psi \iota v \ldots \lambda \alpha \mu \pi \rho \grave{\alpha} v$, SC 188, 74). He then reminds his audience of his first example of vainglory, a young whore possessed by an evil spirit whose

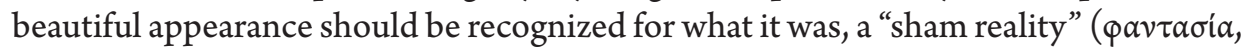

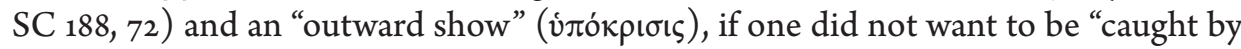
its stage tricks" ( $\pi \varepsilon \rho \iota \pi \varepsilon \sigma o v ́ \mu \varepsilon \theta \alpha \tau \tilde{\eta}$ $\sigma \kappa \eta v \tilde{\eta}) .{ }^{79}$ Taking up his assembly scene again John describes how the honour-loving man "bows to the crowd" (SC 188, 89) in response to their admiration. The theatrical metaphors stress the staged nature of the honorific process in order to suggest that, like the young courtesan, public praise is only a façade for a more ugly truth. ${ }^{80}$

In the following paragraphs John describes the downfall of the honour-loving man. When the costly spectacles have ended he leaves the theatre under the same acclamations as before, although now, John specifies, there "are no longer so many in the crowd" (SC 188, 95). In the afternoon these events are repeated and the benefactor's lavish outlay continues for two or three days until he has spent his entire fortune and is condemned to begging in the market. At this point the true nature of the people is revealed, as they rejoice about his misfortune thinking it "a consolation for their own domestic troubles that the man who had been so glorious was likely to be the most dishonored (á $\tau \mu$ ó $\tau \varepsilon \rho o v)$ of all" (SC 188, 82). According to John, the people's reaction shows how benefactors are not honoured for their gifts but "because they are expected to spend further sums for the crowd" (SC 188, 86). Whereas the assembly scenes of Chariton and Dio call attention to civic honours as an appropriate reward and a genuine expression of gratitude, John's account focuses exclusively on its protreptic function. The honour-loving man's need for prestige thus pushes him to keep up his generosity until he is financially ruined. Although this might seem an unlikely scenario, financial ruin on account of excessive benefactions was a real possibility and could even be regarded as the ultimate display of generosity. ${ }^{{ }^{81}}$ In an attempt to secure the goodwill of the assembly, Dio of Prusa, for example, recalls how his grandfather

78 Tr. Reardon, 'Chariton' (above, n. 27), slightly adapted.

79 Tr. Laistner, Christianity (above, n. 68), slightly adapted.

80 On the staged nature of honorific practices see A. Chaniotis, 'Theatre Rituals', in: P. Wilson (ed.), The Greek Theatre and Festivals (Oxford 2007), 48-66.

81 Zuiderhoek, 'Ambiguity of Munificence' (above, n. 15), 202, calls attention to an honorific inscription from first-century B. C. Epidaurus $\left(I G I^{2}, 165\right)$ that praises a certain Aristoboulus for being so generous that he endangered his own livelihood. Roskam, 'John Chrysostom' (above, n. 70), 160, n. 40, adduces Plut. Mor. 822D-823E and Dio Or. 66.3 as evidence for the dangers of excessive euergetism. 
had spent his entire inheritance on benefactions until he had nothing left for himself (46.3). Nevertheless, according to John, even for moderate benefactors "the glory and

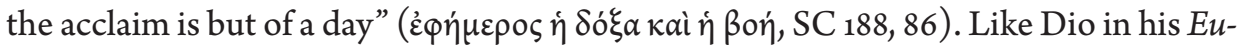
boicus three centuries earlier, John stresses the short-lived nature of popular praise and the fickleness of popular opinion. Yet, in contrast with Dio, he uses these arguments in order to undermine the driving force of the euergetic phenomenon, the elites' $\varphi \mathrm{L}-$

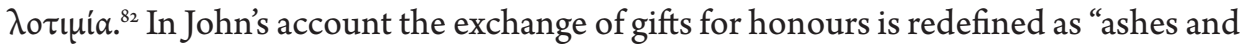
dust for those who expend much and reap nothing" (SC 188, 84).

From John's sermon, which only makes sense as a criticism of a real, existing situation, it appears that honorific discourse still functioned in much the same way in public meetings at the end of the fourth century as it did in the preceding centuries. ${ }^{8_{3}}$ John's redefinition of civic honours as an instance of vainglory, which he regarded as one of the most dangerous vices, could suggest that the fate of civic munificence in an increasingly Christian society was sealed. Nevertheless, it seems that the rhetoric of honour was slow to die, as can be seen from an Aphrodisian inscription dating to the first half of the sixth century. On the columns of the building dedicated or restored by a certain Albinus we can read the following acclamations: "Albinus clarissimus

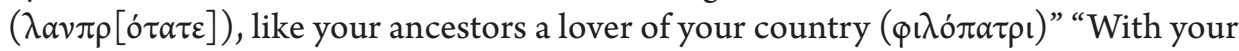
buildings you have made the city brilliant, Albinus, lover of your country ( $\varphi$ i ó $\pi \alpha-$ $\tau \rho \mathrm{l}) .{ }^{{ }^{4}}$

\section{Conclusion}

Taken together, the evidence from the four radically different textual genres discussed in this paper - the novel, oratory, epigraphy and a sermon - attests to a widely distributed political discourse on civic honours that extended from the late classical into the late antique period. In this article I have argued that the assembly scenes of Chariton, Dio of Prusa and John Chrysostom provide a key to understanding the political processes and ideological programme behind honorific inscriptions. An analysis of the rhetoric of honour in these ekklesia scenes has yielded two general conclusions.

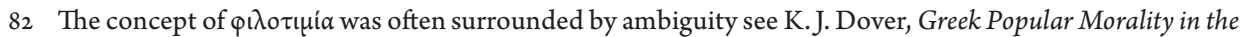
Time of Plato and Aristotle (Oxford 1974), 230-234; Veligianni-Terzi, Wertbegriffe (above, n. 1), 222-223,

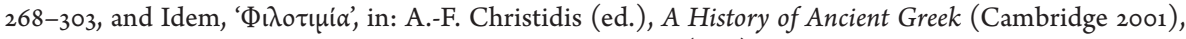
1130-1136; G. Roskam, M. De Pourcq and L. Van der Stockt (eds.), The Lash of Ambition: Plutarch, Imperial Greek literature and the Dynamics of Philotimia (Leuven 2012).

83 This seems to be confirmed by other texts. Robert 'Tpoøev́s' (above, n. 71), 570-571, points to the accla-

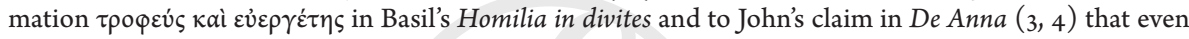
the politicians' children were introduced to munificence. Libanius emphasises the effect of the people's silence (Or. 33.12) and acclamations (Or. 45.22; Or. 46.5 and 39) on officials. On the coexistence of pagan liberalitas and Christian caritas in late antiquity see P. Van Nuffelen, 'Social Ethics and Moral Discourse in Late Antiquity', in: Matz, Leemans and Verstraeten, Patristic Texts (above, n. 69), 43-61.

$84 \mathrm{Ala}_{2004} 83$ nos. xvii and xix, with C. Roueché, 'Acclamation in the Later Roman Empire: New Evidence from Aphrodisias', JRS 74 (1984), 181-199. 
Firstly, honorific language was not confined to inscribed monuments but constituted a real-life discourse that was actively used within the civic context of the popular assembly. The rhetoric of honour functioned as an interpretative repertoire, a wellknown set of terms representing a distinct way of giving meaning to the world that served as a flexible resource in public communication..$^{85}$ Secondly, the ideology of reciprocity, expressed in and sustained by the rhetoric of honour, ensured that both gifts and honours could be used strategically. In the first assembly scene we saw how the demos made rhetorical use of the discourse of honour reminding a member of the elite of his responsibility for generosity, implicitly signalling him that a violation of this responsibility would result in a decrease in status. The powerful effects of the rhetoric of honour are also visible in John's assembly scene where the protreptic aspect of popular acclamations drives the honour-loving man to his ruin. Furthermore, the Euboicus points to the existence of a discourse on the bad citizen that functioned as a counterpart to the rhetoric of honour. Whereas good citizenship was rewarded and solicited through public acclamation, bad citizenship was publicly reprimanded and resulted in the loss of face and political legitimacy.

These conclusions have wider implications for both historical and literary research. For literary scholars it is important to realize how close these assembly scenes were to contemporary civic politics. Although current scholarship no longer regards imperial Greek literature as either a product of elite nostalgia for the classical past or a 'belles-lettres mentality' separated from historical reality, it has not fully recognized the importance of the local political context for our understanding of these fictional stories, what their authors intended with them, and how they were read in antiquity. The strong presence of a real-life political discourse in the assembly scenes of Chariton's Chaireas and Callirhoe and Dio's Euboicus shows that these fictional works were firmly embedded in the socio-political realities of the imperial Greek city. Whereas Chariton employs the rhetoric of honour in order to highlight the magnitude of his love story and ground his fiction in the extra-diegetic world of his reader, the Euboicus contains a complicated tale-within-a-tale that entertains the audience while drawing attention to the dangers inherently connected to assembly politics.

For historians it is important to note that each of the assembly scenes under consideration attests to the vitality of a Greek tradition of people politics, that is, a dialogue between elite and non-elite citizens which was grounded in a civic discourse that provided the people with the ideological means to assert real influence on the political process in the assembly. If the assembly scenes indeed present a fairly accurate image of contemporary realities, as I have argued, this would mean that the balance of power in the imperial Greek cities was not as heavily tilted against the demos as the current consensus would have it. Thus the fact that inscriptions mention the demos as a decision-making body alongside the boule well into the third century A. D. is indeed

85 On discourses as interpretative repertoires see M. Wetherell and J. Potter, 'Discourse Analysis and the Identification of Interpretative Repertoires', in: A. Antaki (ed.), Analysing Everyday Explanation (London 1988), $168-183$. 
likely to be an indication of popular power rather than just an administrative convention. $^{86}$

\section{THIERRY OPPENEER}

Ghent University, Departments of History and Literary Studies, Blandijnberg 2, B-900o Ghent, Thierry.Oppeneer@UGent.be

86 For studies that trivialise the assembly's role in civic politics see notes 5 and 9 above. 